\title{
Epigenetic impact of infection on carcinogenesis: mechanisms and applications
}

\author{
Naoko Hattori and Toshikazu Ushijima*
}

\begin{abstract}
Viral and bacterial infections are involved in the development of human cancers, such as liver, nasopharyngeal, cervical, head and neck, and gastric cancers. Aberrant DNA methylation is frequently present in these cancers, and some of the aberrantly methylated genes are causally involved in cancer development and progression. Notably, aberrant DNA methylation can be present even in non-cancerous or precancerous tissues, and its levels correlate with the risk of cancer development, producing a so-called 'epigenetic field for cancerization'. Mechanistically, most viral or bacterial infections induce DNA methylation indirectly via chronic inflammation, but recent studies have indicated that some viruses have direct effects on the epigenetic machinery of host cells. From a translational viewpoint, a recent multicenter prospective cohort study demonstrated that assessment of the extent of alterations in DNA methylation in non-cancerous tissues can be used to predict cancer risk. Furthermore, suppression of aberrant DNA methylation was shown to be a useful strategy for cancer prevention in an animal model. Here, we review the involvement of aberrant DNA methylation in various types of infection-associated cancers, along with individual induction mechanisms, and we discuss the application of these findings for cancer prevention, diagnosis, and therapy.
\end{abstract}

\section{Background}

Viral and bacterial infections are strongly related to human carcinogenesis, and viral infections account for 10$15 \%$ of human cancers worldwide [1, 2]. Infectionassociated cancers (Table 1) include hepatocellular carcinomas (HCCs) induced by the hepatitis B virus (HBV) and hepatitis $\mathrm{C}$ virus (HCV) [3-5]; lymphomas, nasopharyngeal cancers (NPCs), and gastric cancers associated with the Epstein-Barr virus (EBV) [6, 7]; cervical and head and neck squamous cell cancers (HNSCCs) induced by human papillomavirus (HPV) $[8,9]$; Merkel cell carcinoma associated with Merkel cell polyomavirus $(\mathrm{MCPyV})[10,11]$; and gastric cancers induced by Helicobacter pylori [12]. The carcinogenic mechanisms of these infection-associated cancers have been extensively investigated, focusing on the effects of viral and bacterial infections and the resultant inflammation on cell proliferation, cell signaling, and genetic alterations [1].

\footnotetext{
* Correspondence: tushijim@ncc.go.jp
Division of Epigenomics, National Cancer
Tsukiji, Chuo-ku, Tokyo 104-0045, Japan

Division of Epigenomics, National Cancer Center Research Institute, 5-1-1

* Correspondence: tushijim@ncc.go.jp
Division of Epigenomics, National Cance
Tsukiji, Chuo-ku, Tokyo 104-0045, Japan
}

(c) 2016 Hattori and Ushijima. Open Access This article is distributed under the terms of the Creative Commons Attribution 4.0 International License (http://creativecommons.org/licenses/by/4.0/), which permits unrestricted use, distribution, and reproduction in any medium, provided you give appropriate credit to the original author(s) and the source, provide a link to the Creative Commons license, and indicate if changes were made. The Creative Commons Public Domain Dedication waiver (http://creativecommons.org/publicdomain/zero/1.0/) applies to the data made available in this article, unless otherwise stated.

In addition to these effects, induction of epigenetic alterations is now regarded as one of the most important mechanisms mediating the effect of viral or bacterial infections on cancer development. The first reports of an association between viral infections and DNA methylation date back to the 1970s; these reports demonstrated an increase in global 5-methylcytosine in cells transformed by adenovirus and polyomavirus [13, 14]. In the 2000s, aberrant DNA methylation of tumor-suppressor genes was detected first in EBV-infection-associated cancers [15] and then in gastric mucosae of individuals with H. pylori infection $[16,17]$. To date, many studies have demonstrated a relationship between viral or bacterial infections and aberrant DNA methylation [18-20].

Chronologically, aberrant DNA methylation can already have accumulated in non-cancerous or precancerous tissues, producing an 'epigenetic field defect' or 'epigenetic field for cancerization' [21]. The epigenetic field for cancerization is characterized by accumulation of aberrant methylation of various genes in a tissue without clonal lesions, and by the correlation between the 
Table 1 Infection-associated cancers and aberrant DNA methylation

\begin{tabular}{|c|c|c|c|c|}
\hline $\begin{array}{l}\text { Bacterium or } \\
\text { virus }\end{array}$ & Cancer type & Tumor-suppressor genes methylated & $\begin{array}{l}\text { Direct or } \\
\text { indirect effect }\end{array}$ & $\begin{array}{l}\text { Factors involved in induction } \\
\text { of aberrant methylation }\end{array}$ \\
\hline Helicobacter pylori & Gastric cancer & $\begin{array}{l}\text { p16, LOX [39], miR-124a [47], miR-34b/c [48], } \\
\text { ANGPTL4 [46], FHL1 [44] }\end{array}$ & Indirect & Inflammation \\
\hline \multirow[t]{3}{*}{ Epstein-Barr virus } & Gastric cancer & p73 [72], TFF1 [73] & $\begin{array}{l}\text { Direct and/or } \\
\text { indirect }\end{array}$ & Latent membrane proteins \\
\hline & Nasopharyngeal cancer & $\begin{array}{l}\text { DLC1 [79], DAPK [77], p15, p16, RASSF1A, } \\
\text { TSLC1 [78] }\end{array}$ & Unknown & Unknown \\
\hline & Burkitt's lymphoma & BIM, PRDM1 [84] & Unknown & Unknown \\
\hline Hepatitis $B$ virus & Hepatocellular carcinoma & $\begin{array}{l}\text { p16 [97], p21, CDH1 [18], SOCS1 [103], } \\
\text { RASSF1A, GSTP1 [98] }\end{array}$ & $\begin{array}{l}\text { Direct and/or } \\
\text { indirect }\end{array}$ & $\mathrm{HBx}$ and inflammation \\
\hline Hepatitis C virus & Hepatocellular carcinoma & p16 [97], RASSF1A, GSTP1 [98], RIZ1 [103] & Indirect & Inflammation \\
\hline \multirow[t]{2}{*}{$\begin{array}{l}\text { Human } \\
\text { papillomavirus }\end{array}$} & $\begin{array}{l}\text { Head and neck squamous } \\
\text { cell carcinoma }\end{array}$ & $\begin{array}{l}\text { P16, CDH1, RARß [115], MGMT [114], } \\
\text { DAPK [113], DCC, GALR1, GALR2 }\end{array}$ & Unknown & Unknown \\
\hline & Cervical cancer & $\begin{array}{l}\text { p16, FHIT, GSTP1, MGMT [120], MAL [122], } \\
\text { TSLC1 [123] }\end{array}$ & Unknown & Unknown \\
\hline $\begin{array}{l}\text { Merkel cell } \\
\text { polyomavirus }\end{array}$ & Merkel cell carcinoma & RASSF1A [161] & Unknown & Unknown \\
\hline
\end{tabular}

HBx HBV encoded protein $\mathrm{X}$

'severity' of a field and cancer risk [21]. The clinical relevance of this concept has recently been demonstrated by a multicenter prospective cohort study to predict risk of metachronous gastric cancer [22].

Mechanistically, aberrant DNA methylation can be induced directly by a component(s) of an infectious agent, as recently shown for EBV [19, 23, 24]. Alternatively and more commonly, aberrant DNA methylation can be induced by chronic inflammation, as robustly shown for H. pylori and hepatitis viruses $[25,26]$. In addition, a recent study suggested that chronic inflammation could induce histone modification changes more frequently and much earlier than aberrant DNA methylation, and that some of the aberrant histone modifications can serve as a signal for aberrant DNA methylation [27].

In this review, we first summarize the effect of $H$. pylori infection, whose role in induction of aberrant DNA methylation and gastric carcinogenesis has been intensively studied, and introduce the mechanisms of how $H$. pylori infection induces aberrant DNA methylation. Then, we introduce several viral infections that induce aberrant epigenetic alterations, especially DNA methylation, and discuss the mechanisms involved. Finally, we discuss the applications of infection-induced epigenetic alterations for cancer prevention, diagnosis, and therapy.

\section{Helicobacter pylori in gastric cancers}

The vast majority of gastric cancer cases worldwide are induced by $H$. pylori infection. It is an archetypal cancer in which chronic inflammation and epigenetic alterations are interconnected. The mechanisms by which $H$. pylori infection induces aberrant DNA methylation have been investigated in gastric cancers, cell lines, and animal models $[25,28]$. The epigenetic nature of gastric cancer was recently reported [29].

\section{Association among H. pylori infection, epigenetic alterations, and gastric cancer}

Gastric cancer is one of the most common malignancies worldwide, especially in Asia and some European countries [30]. The major risk factor is persistent H. pylori infection [31]; risk is elevated 2.2- to 21 -fold by H. pylori infection [12, 32, 33]. In some Asian countries, nearly all gastric cancer patients have a history of $H$. pylori infection [2]. H. pylori is a Gram-negative bacterium [34, 35] and is thought to be transmitted orally within families during early childhood owing to poor hygiene. Few bacteria can survive in the stomach because of its low $\mathrm{pH}$ maintained by the production of gastric acids; however, H. pylori can survive for decades because of its production of urease, which neutralizes its immediate environment [36]. It induces chronic gastritis characterized by persistent infiltration of neutrophils and mononuclear cells, and gastric atrophy [37]. Gastric atrophy is also a strong risk factor for gastric cancer (hazard ratio $=14.09$ (95\% confidence interval $(\mathrm{CI})=7.03-28.26)$ ) [38]

Deep involvement of aberrant DNA methylation in human gastric cancers had been suggested by the fact that tumor-suppressor genes, such as $C D H 1, p 16$, and $h M L H 1$, were inactivated more frequently by aberrant DNA methylation of their promoter CpG islands than by genetic alterations [39]. More recently, integrated analysis of DNA methylation and genetic alterations in gastric cancer has revealed that genes involved in cancer-related pathways were more frequently affected by DNA methylation than by genetic alterations $[29,40]$. 
Furthermore, recent exome and whole-genome analyses of gastric cancers have revealed new mutated driver genes, such as ARID1A, FAT4, and RHOA, but the incidences of mutations were $14 \%$, at the most, among the cancers analyzed [41, 42]. Importantly, a significant number of cancers have few mutations; according to a report by Wang et al. [41], 5 of 100 cancers had no mutations, and 22 cancers had only one mutation. These reports support the major role of DNA methylation in gastric cancer.

The link between $H$. pylori infection and DNA methylation in gastric mucosae was first discussed in two contradictory reports in 2003. Chan et al. [43] demonstrated that promoter methylation of the tumorsuppressor gene $C D H 1$ was more frequent in the gastric mucosae of individuals with $H$. pylori infection than in uninfected individuals. In contrast, Kang et al. [16] did not detect a difference in the number of methylated genes between the gastric mucosae of individuals with and without $H$. pylori infection. A quantitative DNA methylation analysis of passenger genes (defined as those that do not have a causal role in carcinogenesis) [17] later convincingly demonstrated that $H$. pylori infection was associated with increased DNA methylation levels in gastric mucosae. These findings highlight the importance of accurate quantification of DNA methylation and analysis of appropriate genes.

The increased DNA methylation levels in noncancerous gastric mucosae with $H$. pylori infection were observed in various but specific genes, including a small number of tumor-suppressor genes, such as p16, ANGPTL4, and FHL1, and a large number of passenger genes [44-46]. In addition to protein-coding genes, microRNA genes, including $m i R-124 a$ and $m i R-34 b / c$, were also aberrantly methylated in non-cancerous gastric mucosae infected with $H$. pylori $[47,48]$. Importantly, the levels of DNA methylation of various methylated genes were relatively consistent and correlated with the risk of gastric cancer development [17, 49].

To investigate the cell types with aberrant methylation of these genes, normal gastric epithelial cells were purified from an animal model, and the presence of aberrant DNA methylation in these gastric epithelial cells was shown [25]. Three positions within the stomach (antrum, middle body, and upper body) had increased methylation levels in individuals with high risk of gastric cancers compared with corresponding positions in the stomach in individuals with low risk [49].

Therefore, aberrant DNA methylation of various specific genes is accumulated in normal gastric epithelial cells in various positions within the stomach of individuals with high risk of gastric cancers, and an 'epigenetic field defect' or an 'epigenetic field for cancerization', which is an area or even an entire tissue predisposed to cancer development, is produced [21]. Generally, the presence of a cancerization field has been known for decades, but it has been explained by mutation accumulation [50]. Now, based on the findings in gastric cancer [21], accumulation of epigenetic alterations in noncancerous or precancerous tissue has been shown to be important. The concept is likely to be expanded to several types of other infection-associated cancers, and has great value as a risk marker, as discussed later.

\section{Mechanisms of induction of aberrant DNA methylation by H. pylori infection}

From the viewpoint of $H$. pylori infection-induced gastric carcinogenesis, most research has traditionally focused on cell proliferation, induction of genetic instability and mutations, and activation of cellular signaling [51-54]. For example, in the Mongolian gerbil animal model (Meriones unguiculatus), in which $H$. pylori infection markedly promotes gastric carcinogenesis by a mutagen such as $\mathrm{N}$-methyl- $\mathrm{N}$-nitrosourea [55], chronic inflammation due to $H$. pylori infection was shown to induce increased cell proliferation, and this may cause further accumulation of mutations [56]. However, induction of aberrant DNA methylation can be even more important as described above.

Aberrant DNA methylation can potentially be induced by two mechanisms: directly by a component of $\mathrm{H}$. pylori, such as DNA methyltransferase, being injected into gastric epithelial cells through a bacterial type IV secretion system [57]; or indirectly due to inflammation triggered by $H$. pylori infection. To clarify which mechanism is important, Niwa et al. [25] used Mongolian gerbils, in which aberrant DNA methylation was induced by $H$. pylori infection in a manner similar to that observed in humans. They treated gerbils infected with $H$. pylori with an immunosuppressant, cyclosporine $\mathrm{A}$, and found that the induction of aberrant DNA methylation was strongly suppressed, whereas $H$. pylori colonization itself was not affected or was even augmented [25]. In addition, one week after $H$. pylori eradication, when no $H$. pylori remained in the stomach but inflammation still persisted, aberrant DNA methylation continued to be induced. These data showed that inflammation triggered by $H$. pylori infection, but not by $H$. pylori itself, is involved in induction of aberrant DNA methylation (Fig. 1).

The next questions are what types of inflammation are involved in DNA methylation induction and what cytokines or molecules mediate the signal from the inflammation. In gerbils, repeated administration of high concentrations of ethanol or salt $(\mathrm{NaCl})$ induced persistent severe inflammation accompanied by strong induction of cell proliferation, but did not result in induction of aberrant DNA methylation [28]. H. pylori infection 


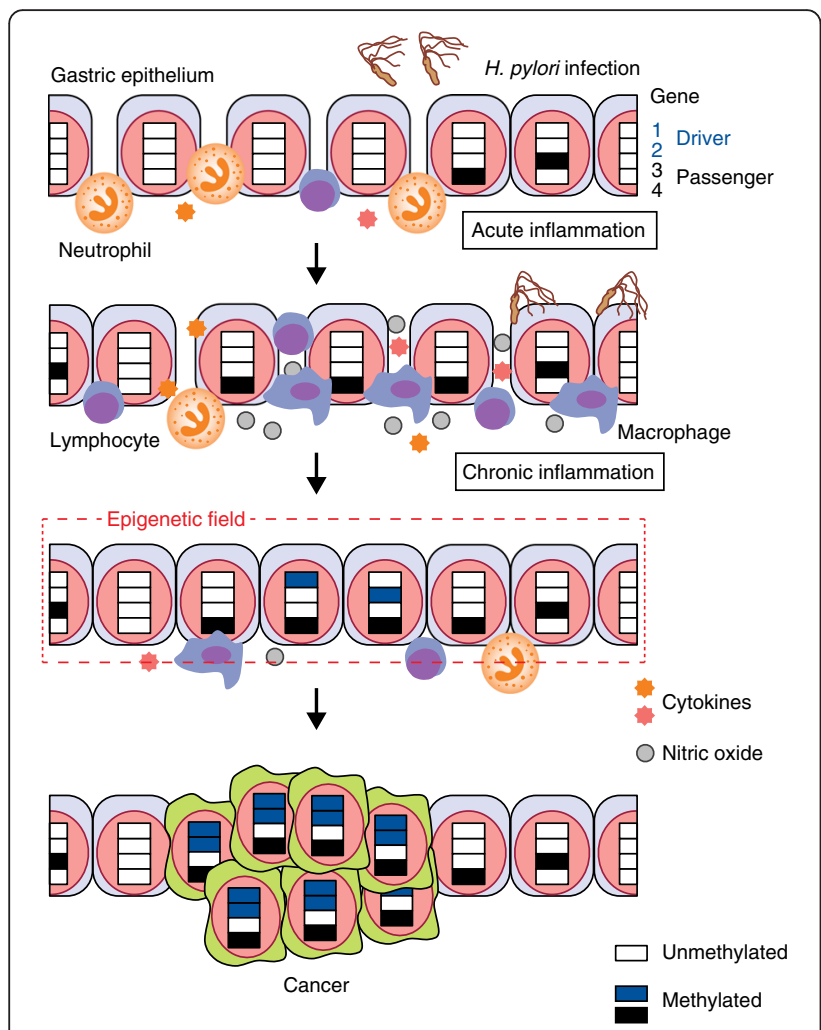

Fig. 1 Mechanisms of induction of aberrant DNA methylation by $H$. pylori infection. Acute inflammation following infection by H. pylori develops into chronic inflammation characterized by the transition of neutrophil infiltration to that of lymphocytes and macrophages. Chronic inflammation signals, including cytokines such as IL-1 $\beta$ and TNF-a and/or nitric oxide production, are associated with the induction of aberrant DNA methylation. Aberrant DNA methylation is induced both in driver genes (schematically represented by genes 1 and 2) that are causally involved in gastric cancer development and in passenger genes (genes 3 and 4) that are methylated in association with gastric carcinogenesis in normal-appearing tissues. Driver genes are methylated only at very low levels (shown in blue), showing that such events are present only in a very small fraction of cells, whereas many passenger genes are methylated at high levels (shown in black), showing that their methylation is present in a large fraction of cells. The accumulation of aberrant DNA methylation in normal-appearing tissues produces an 'epigenetic field for cancerization', which is an area of tissue or an entire tissue without clonal growth but predisposed to cancer development

induces chronic inflammation, characterized by a transition of inflammatory cell types from polymorphonuclear cells (mainly neutrophils) to mononuclear cells (lymphocytes and macrophages), with some remnant neutrophils [58]. In contrast, prolonged treatment with ethanol or salt induced repeated acute inflammation, characterized by persistent neutrophil infiltration [28]. This indicates that a specific type of inflammation, possibly characterized by mononuclear cell infiltration, is required for induction of aberrant DNA methylation.

Regarding the responsible cytokines or molecules, increased expression of $C x c l 2, I l 1 b$, and $\operatorname{Tnf}$ (which encode cytokines) and Nos2 (which encodes nitric oxide (NO) synthase) were present in gastric mucosae of gerbils with H. pylori infection, but not in those of gerbils exposed to ethanol- or salt-induced inflammation [42]. The potential involvement of $I L 1 B$ in human gastric cancer is further evidenced by the association between polymorphisms in the $I L 1 B$ promoter and gastric cancer susceptibility, especially among individuals with $H$. pylori infection [59, 60], although $I l 1 b$-deficient mice were resistant to $H$. pylori-induced gastric cancers [61]. IL1B promoter polymorphisms were also associated with the presence of the $\mathrm{CpG}$ island methylator phenotype, a distinct phenotype with frequent aberrant DNA methylation of multiple CpG islands, in gastric cancers [62]. Also, treatment of gastric cancer cell lines (TMK-1, MKN-74, and MKN-7) with IL-1 $\beta$ has been reported to have induced the methylation of tumor-suppressor gene $C D H 1$, based on a conventional methylation-specific PCR [62, 63].

NO, whose production is enhanced by an $H$. pylori extract [64] and IL-1 [65], was reported to upregulate the enzyme activity of DNA methyltransferases (DNMTs) without affecting mRNA expression levels [65]. However, the enhancement of DNMT activity by NO has not been confirmed since then. In addition, no changes in the mRNA level of genes encoding DNMTs have been observed in human or gerbil stomachs infected with $H$. pylori $[25,66]$ and in mouse colonic epithelial cells exposed to chronic inflammation [67]. Therefore, the molecules involved in the addition or maintenance of a methyl group are unlikely to be affected, and we suggest that factors that protect DNA from methylation, such as TET proteins, are likely to be affected by chronic inflammation, possibly via signals from macrophages, such as IL-1 $\beta$, TNF- $\alpha$, or NO (Fig. 1).

\section{EBV and cancer}

EBV was the first virus detected in human neoplastic cells (in a Burkitt's lymphoma cell line), in 1964 [68], and is involved in several tumor types. It was recently shown to have a direct effect on induction of aberrant DNA methylation based on an infection system of recombinant EBV in vitro [19, 23, 24].

\section{Association among EBV infection, epigenetic alterations, and cancer}

EBV infection is epidemiologically associated with development of human tumors, such as Burkitt's lymphoma, Hodgkin's lymphoma, peripheral natural killer/T-cell lymphoma, smooth muscle tumor, NPCs, and gastric cancer [7]. EBV, a gamma-herpes virus consisting of double-stranded DNA, maintains itself as an episomal circular DNA in the nuclei of infected cells without the production of viral particles, and it is not integrated into the host genome $[69,70]$. Although more than $90 \%$ of 
the world population is infected with EBV before adolescence and become lifelong virus carriers, malignant neoplasms develop in a limited number of carriers.

Approximately $10 \%$ of all gastric cancer cases are EBV-associated, and monoclonal growth of EBV-infected gastric epithelial cells is detected in gastric mucosae [71]. Aberrant DNA methylation was observed more frequently in $\mathrm{EBV}^{+}$cancers than in $\mathrm{EBV}^{-}$cancers [15], and hypermethylation of several specific genes, such as $p 73$ and TFF1, has also been reported [72, 73]. Genome-wide effects of EBV on DNA methylation were revealed by Matsusaka et al. [74], and gastric cancers were categorized into three distinct groups, $\mathrm{EBV}^{-}$and low methylation, $\mathrm{EBV}^{-}$and high methylation, and $\mathrm{EBV}^{+}$and extensively high methylation.

In nasopharyngeal cancer, $70-90 \%$ of the differentiated type is associated with EBV infection [75], and premalignant lesions of the nasopharyngeal epithelium are $\mathrm{EBV}^{+}$, suggesting the occurrence of EBV infection at an early step in carcinogenesis [76]. In primary cancers, aberrant DNA methylation has been observed at tumorsuppressor genes, including DAPK1, DLC1, p15, p16, and RASSF1A [77-79]. Significant association has been observed between the levels of promoter methylation of RASSF1A and TSLC1 tumor-suppressor genes and the quantity of EBV DNA detected in cancer tissues and in adjacent and distant non-cancerous tissues [78].

In lymphoma, EBV is present in over $95 \%, 5-10 \%$, and $3-40 \%$ of endemic, sporadic, and HIV-associated Burkitt's lymphoma cases, respectively [80], in approximately $40 \%$ of Hodgkin's lymphoma cases [81], and in 2-9 \% of diffuse large B-cell lymphoma cases [82]. Aberrant DNA methylation of tumor-suppressor genes, including BIM and PRDM1, was detected in $\mathrm{EBV}^{+}$Burkitt's lymphoma cases but not in $\mathrm{EBV}^{-}$cases [83, 84]. Hansen et al. [85] identified large-scale hypomethylated blocks, which encompassed several Gb or were at least longer than $1 \mathrm{Mb}$, in EBV-transformed $\mathrm{B}$ cells by a genome-wide analysis, suggesting that at the early stage of EBV-associated carcinogenesis, global hypomethylation occurs first, leading to genome instability and eventually to the induction of aberrant DNA methylation.

\section{Mechanisms of induction of aberrant DNA methylation by EBV}

The causal role of EBV infection in inducing high levels of DNA methylation was confirmed by forcing EBV expression in a gastric cancer cell line and observing acquisition of new DNA methylation within 18 weeks [19]. Introduction of latent membrane protein 1 (LMP1), a viral oncoprotein from EBV, into a breast cancer cell line (MCF-7) activated DNMT1, DNMT3A, and DNMT3B, and induced methylation-silencing of tumor-suppressor gene CDH1 [86]. LMP1 directly activated the DNMT1 promoter via the JNK-AP1 pathway [87]. Latent membrane protein 2A (LMP2A) also induced DNMT1 overexpression via STAT3 activation [88], which led to methylation-silencing of tumor-suppressor gene PTEN. In contrast with epithelial cells, EBV infection of germinal center B cells, the presumptive progenitors of Hodgkin's lymphoma, down-regulated DNMT1 and DNMT3B via LMP1, whereas DNMT3A was upregulated at the mRNA and protein levels [89]. Taken together, EBV infection is considered to induce aberrant DNA methylation by its direct effect, namely via dysregulation of DNMTs (Fig. 2).

\section{HBV and HCV and hepatocellular carcinoma}

Infections by $\mathrm{HBV}$ and $\mathrm{HCV}$ induce chronic hepatitis, and are the major cause of HCC. Involvement of aberrant DNA methylation has been suggested by the

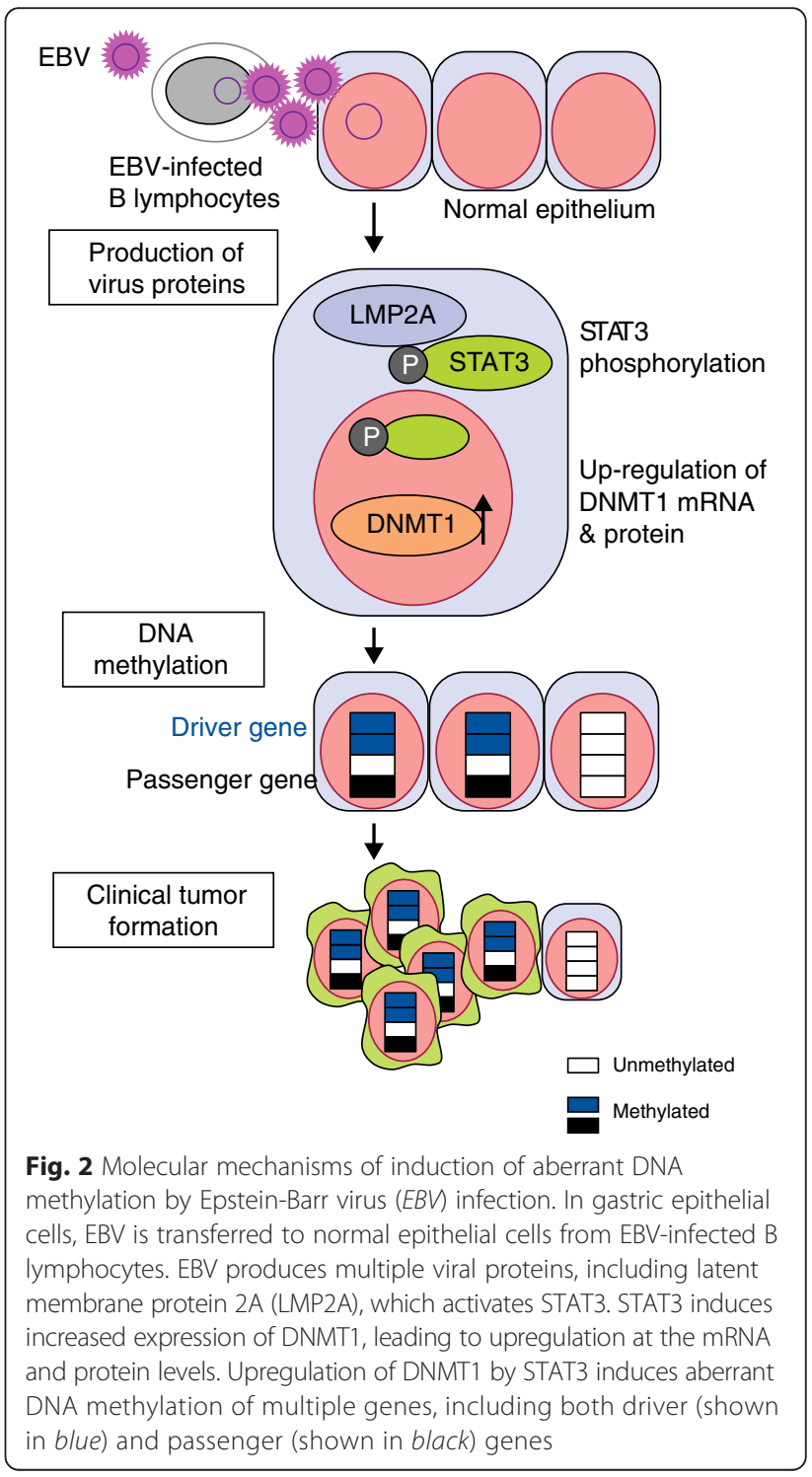


increase of aberrantly methylated genes during disease progression (from chronic hepatitis to liver cirrhosis and to HCC). A recent report also showed the importance of the immune response in the induction of methylation by HBV or HCV [26].

HBV is a DNA virus and can be integrated into the host genome, leading to virus-related insertional mutagenesis of tumor-related genes [90]. However, it used to be considered that there was no consensus pattern of insertional mutations among HBV-induced HCC samples $[3,91,92]$. Recent whole-genome sequencing analysis of HCCs revealed that, although HBV was frequently integrated into the TERT locus, most other frequently mutated genes had incidences of less than $10 \%$ [93, 94]. $\mathrm{HCV}$ is an RNA virus and cannot be integrated into the host genome, but HCV core protein interacts with multiple proteins of host cells and these interactions induce host responses $[95,96]$.

\section{Association among hepatitis virus infection, aberrant DNA} methylation, and hepatocellular carcinoma

Epigenetically, similar to cancers of other tissues, HCCs are characterized by hypomethylation of repetitive sequences, associated with genomic instability, and aberrant DNA methylation of tumor-suppressor genes, such as RASSF1A, p16, SFRP1, GADD45A, and $p 15[18,97$, 98]. These epigenetic alterations accumulate during the course of HCC development [99]. For example, decreased methylation at the LINE- 1 and satellite 2 repetitive elements was mainly observed when chronic hepatitis and liver cirrhosis progressed to HCC [100], and methylation of CHFR and SYK, potential tumor-suppressor genes, increased in advanced HCC [101, 102]. These findings suggest that accumulation of aberrant DNA methylation in non-cancerous tissues, or an epigenetic field for cancerization that is predisposed to cancer development, may also be present in HCC, similar to that described above for $H$. pylori infection in gastric cancer.

Importantly, the DNA methylation profile of liver cirrhosis and HCC is dependent on the type of hepatitis virus. Nishida et al. [103] showed that methylated loci were categorized into three groups: i) loci methylated in normal tissues and that showed increased methylation during HCC development; ii) loci methylated in noncancerous and HCC tissues; and iii) loci methylated more densely and frequently in $\mathrm{HCV}^{+} \mathrm{HCC}$ than in $\mathrm{HBV}^{+}$and virus-negative HCC. Other analyses of genome-wide DNA methylation data also showed etiology-dependent methylation profiles of cirrhosis and primary HCC $[104,105]$.

\section{Mechanisms of induction of aberrant DNA methylation by} $\mathrm{HBV}$ and HCV

Aberrant DNA methylation may be induced by direct action of a virus and also indirectly via chronic inflammation due to viral infection (Fig. 3). A direct action is known for an HBV protein, hepatitis B virus protein $\mathrm{X}(\mathrm{HBx}) . \mathrm{HBx}$ was found to induce $D N M T$ upregulation, leading to DNA methylation of the genes involved in the Ras pathway and angiogenesis [106], and to interact directly with DNMT3A to recruit it to the promoters of $I L-4 R$, a gene encoding a cytokine receptor involved in apoptosis, and $M T 1 F$, a potential tumor-suppressor gene, leading to their methylationsilencing [107].

Chronic inflammation is also involved in the induction of aberrant DNA methylation and thus in the production of an epigenetic field for cancerization, similar to the gastric carcinogenesis associated with $H$. pylori infection (Fig. 3). Okamoto et al. [26] analyzed genome-wide DNA methylation in the livers of immunodeficient mice

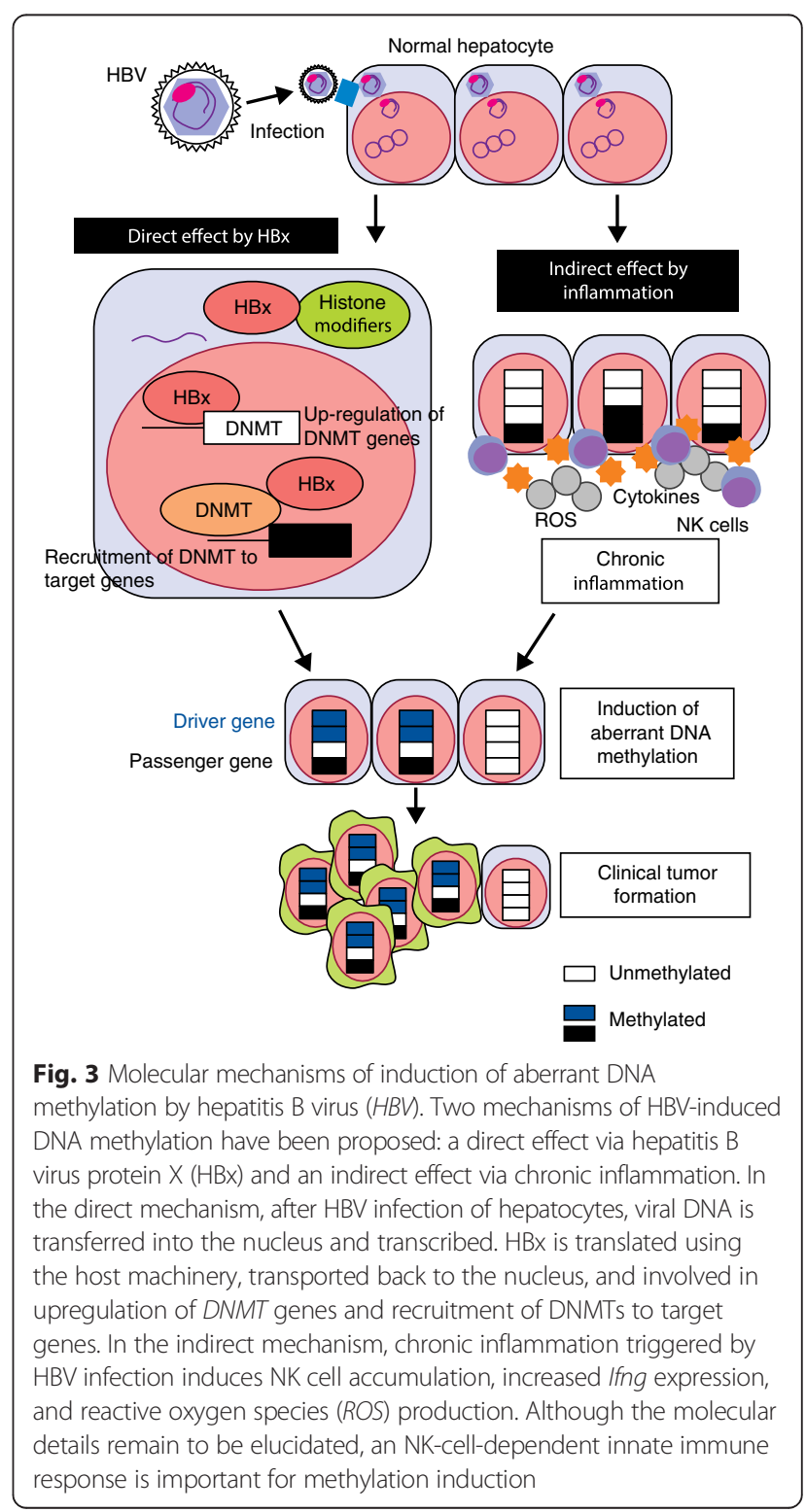


carrying human hepatocytes infected with HBV or HCV. In both systems, aberrant DNA methylation was induced, and the induction was associated with increased expression of an inflammation-related gene, Ifng, produced by NK cells, and reactive oxygen species (ROS) production. When NK cell activity was suppressed by the anti-asialo-GM-1 antibody, the induction of aberrant DNA methylation was suppressed, demonstrating that the NK-cell-dependent innate immune response was important for methylation induction [26].

\section{Human papillomaviruses and squamous cell carcinomas}

Human papillomavirus (HPV) is related to the development of HNSCC and cervical cancers [108]. Although details of a mechanistic link between HPV and aberrant DNA methylation are still very limited, clinical application of aberrant DNA methylation in detection of cervical cancers is now actively being investigated [109].

HPV is a circular, double-stranded DNA virus, and more than 100 unique HPV types are known [110]. Among them, HPV types 16, 18, 31, 33, 35 and 45 are high-risk HPV (hrHPV) [108]; 12.5-25 \% of HNSCCs are associated with infection by hrHPV types 16,33 , or 35 , and HNSCCs in the oropharynx are particularly strongly associated [110, 111]. Approximately $54 \%$ and $17 \%$ of invasive cervical cancer cases are associated with hrHPV types 16 and 18, respectively [112].

Promoter hypermethylation is considered to be a mechanism of HNSCC progression, although analysis has been limited to a small number of tumor-suppressor genes, such as p16, CDH1, RAR $, M G M T, D A P K, D C C$, GALR1, and GALR2 [113-115]. Methylation was more frequently observed in $\mathrm{HPV}^{+}$cells than in $\mathrm{HPV}^{-}$cells, and DNMT3A expression was also higher in $\mathrm{HPV}^{+}$cell lines [116-118]. Methylation levels of LINE-1 repetitive elements were higher in $\mathrm{HPV}^{+} \mathrm{HNSCC}$ than in $\mathrm{HPV}^{-}$ cancer cells [119]. This finding was interesting, considering that most cancer cells are characterized by global hypomethylation, including LINE-1 repetitive elements [100]. The authors [100] suggested that HPV-infected cells attempted to silence the virus by DNA methylation, which might have resulted in increased methylation of LINE-1 repetitive elements [119].

In cervical cancer, increased DNA methylation of tumor-suppressor genes, such as p16, FHIT, GSTP1, $M A L$ and TSLC1, was observed [120-123]. Some of these genes, such as CADM1 and MAL, were also methylated in cervical intraepithelial neoplasia (CIN), a precancerous lesion associated with hrHPV infections [124, 125], providing the presence of an accumulation of aberrant DNA methylation in non-cancerous tissues, or an epigenetic field for cancerization, which is predisposed to cancer development.

\section{Implications for cancer prevention, diagnosis and therapy}

A common characteristic of infection-associated cancers is the presence of an epigenetic field for cancerization [18-20]. In addition to infection-associated cancers, cancers associated with inflammation due to causes other than infection (inflammation-associated cancer), such as Barrett's cancer of the esophagus, are also associated with an epigenetic field [126]. Furthermore, prostate and breast cancers, both of which are associated with hormonal signals [21], are also associated with an epigenetic field $[127,128]$. In addition, DNA methylation in noncancerous tissues has been associated with tumor aggressiveness and worse patient outcome [129]. These findings indicate that opportunities for cancer prevention, diagnosis, and therapy are potentially widely applicable. In particular, cancer risk diagnosis is now reaching a level of clinical use. Examples of such applications for clinical management of infection-associated cancers are summarized in Table 2.

\section{Diagnosis of cancer risk}

The extent of aberrant DNA methylation accumulation in non-cancerous tissues, or the 'severity' of an epigenetic field, correlates with the risk of cancer development, at least in some cancers, including gastric cancer. A recent multicenter prospective cohort study convincingly demonstrated the clinical utility of this concept [22]. In the study, a gastric mucosal biopsy sample was obtained from 826 patients who had undergone endoscopic resection of a gastric cancer, and DNA methylation levels of three preselected marker genes, EMX1, NKX6-1, and miR-124a-3 [47, 130], were measured. After a median follow-up of 2.97 years, the patients with a high methylation level of miR-124a-3 were shown to develop metachronous gastric cancers with a statistically higher incidence (hazard ratio $=2.3, p=0.042$ ). In addition, several promising DNA methylation markers have been identified through retrospective cohort studies [131-133].

Epigenetic cancer risk diagnosis is expected to achieve cancer risk prediction that is very difficult by other

Table 2 Applications for clinical cancer management

\begin{tabular}{ll}
\hline Application & Example \\
\hline $\begin{array}{l}\text { Cancer diagnosis } \\
\text { Cancer risk }\end{array}$ & Prediction of metachronous gastric cancer [22] \\
Cancer prevention & $\begin{array}{l}\text { Early detection of cervical cancer [109] } \\
\text { Suppression of H. pylori-induced gastric cancers } \\
\text { by 5-aza-2'-deoxycytidine in animal model [151] }\end{array}$ \\
Cancer therapy & $\begin{array}{l}\text { DNA demethylating agents and histone } \\
\text { deacetylase inhibitors (not specific to } \\
\text { infection-associated cancers) [155] }\end{array}$ \\
\hline
\end{tabular}


means. This is because the assessed epigenome alteration is considered to reflect a patient's life history, including exposure to environmental carcinogenic factors and how strongly the sampled tissue responded to the carcinogens. Also, DNA methylation levels can be measured precisely and therefore have a methodological advantage. The use of the extent or 'severity' of the epigenetic field as a cancer risk marker is expected to be applicable to various types of cancers.

\section{Early detection of cancers}

In HPV-associated cervical cancers, DNA methylation markers have been found to be useful for triage of hrHPV-positive women as a tool for screening [134]. Several methylation biomarkers were able to distinguish cervical samples with intraepithelial neoplasia grade 2 or 3 (CIN2 or 3) from those with CIN1 or without any intraepithelial lesions or malignancy [135-137]. A recent prospective randomized clinical trial by Verhoef et al. [109] compared methylation of preselected marker genes $M A L$ and $m i R-124-2$ with cytology using self-collected cervicovaginal specimens and showed that methylation triage was at least as sensitive as cytology triage for detection of CIN2 or worse. This large-scale randomized prospective study clearly demonstrates the power of epigenetic analysis in detecting cervical cancer.

In EBV-associated NPC, Hutajulu et al. [138] detected aberrant methylation of four tumor-suppressor genes (DAPK1, DLC1, CDH13, and CADM1) in DNA from nasopharyngeal brushing samples of cancer patients, high-risk subjects, and healthy EBV carriers, and also detected DNA methylation of CDH1, DAPK1, and $p 16$ in the peripheral blood of NPC patients. These reports indicated that the DNA methylation of these genes might be a useful serological marker for screening of primary and local or regional recurrent NPC [139].

\section{Targets for cancer prevention}

Suppression of accumulation of aberrant DNA methylation or elimination of accumulated methylation is expected to lead to a decreased cancer incidence. This concept has been supported by evidence in genetically engineered animal models for colon tumors [140-142], lung tumors [143], blood cancers [144, 145], and squamous cell carcinomas in the tongue and the esophagus [146]. The mechanism has been explained by the induction of cellular differentiation and impairment of stem cell function by decreased methylation due to reduced expression of Dnmt1 [141, 145]. Also, administration of a DNA demethylating agent, such as 5-aza-2'-deoxycytidine, suppressed tumorigenesis in animal models for intestinal tumors [147], prostate cancer [148, 149], and breast cancer [150].
The plausibility of this strategy in infection-associated cancers is of broad interest considering the large population affected by these types of cancers. Niwa et al. [151] showed that administration of 5-aza-2'-deoxycytidine could suppress the development of $H$. pylori-induced gastric cancers in Mongolian gerbils. In humans, because epidemiological studies have shown an inverse association between the use of nonsteroidal anti-inflammatory drugs (NSAIDs) and incidence of colorectal cancer disease-related death, NSAIDs are used to prevent colorectal cancers [152]. Multiple mechanisms have been proposed to explain the inverse association, including enhancement of apoptosis of colonic epithelia [153, 154]. Therefore, it seems possible that suppression of induction of epigenetic alterations might be effective in infection-associated cancers.

\section{Targets for cancer therapy}

Regarding cancer therapy, epigenetic drugs have been developed that target DNA methyltransferases and histone modification regulators (deacetylases, methyltransferases, demethylases, and readers). DNA demethylating agents and histone deacetylase inhibitors have already been approved for hematological malignancies [155, 156]. Clinical trials for a broader range of tumors, including solid tumors, are being extensively conducted, and various combinations of different epigenetic drugs, or an epigenetic drug and an anti-cancer drug, are also being attempted. Although the targets of epigenetic drugs do not appear to be specific to infection-associated cancers compared with other cancers, infection-associated cancers may have more targets because infection is a potent inducer of epigenetic alterations, and some of these cancers might be a good subpopulation for epigenetic therapy.

\section{Conclusions and future directions}

The induction of aberrant DNA methylation now appears to be the major mechanism by which viral and bacterial infections in various tissues can induce cancer. Therefore, the remaining crucial question is the molecular mechanism by which viral and bacterial infections induce epigenetic alterations. It is clear that, for multiple types of infections, aberrant DNA methylation is induced via chronic inflammation, but the molecular mechanisms by which chronic inflammation induces aberrant DNA methylation are mostly still unclear. At the same time, some pathogens, such as EBV and HBV, directly interfere with epigenetic regulators. Clarification of these molecular mechanisms will have great value in identifying novel targets for cancer prevention.

An epigenetic field for cancerization is a common characteristic of infection-associated cancers. In addition, cancers associated with chronic inflammation due to causes 
other than infection also have an epigenetic field [126], because chronic inflammation is a potent inducer of aberrant DNA methylation. Furthermore, the presence of an epigenetic field has been reported for hormone-associated cancers [21]. The direct action of hormones on epigenetic machinery has been suggested [157], and more research in this area is also important.

Epigenetic field cancerization provides a broad range of opportunities for cancer diagnosis, prevention, and therapy. The 'severity' of an epigenetic field for cancerization is promising as a cancer risk marker, as evidenced by the multicenter prospective cohort study for metachronous gastric cancer [22]. Epigenetic cancer risk markers are considered to reflect the life history of individuals and thus can be effective because environmental exposure is a major cause of human cancers [158]. To bring the markers identified in retrospective cohort studies into practice, more prospective studies in settings with high clinical value are necessary. Early detection of cancer is also a promising application of epigenetic markers, and comparison of sensitivity and specificity with markers now used in clinical practice is necessary.

The use of an epigenetic field as a target of cancer prevention is also awaited. Given that the usefulness of suppression of aberrant DNA methylation has been shown for various types of tumors in animal models, development of a method with minimal adverse effects appears essential. However, current DNA demethylating agents decitabine and azacytidine are mutagenic [159] and cannot be used for cancer prevention. Meanwhile, suppression of chronic inflammation is expected to have preventative value through multiple mechanisms [153, 154]. Drug repositioning, which uses drugs already shown to be safe, may also become a useful strategy to identify drugs targeting aberrant DNA methylation or an epigenetic field, leading to inhibition of infectionassociated carcinogenesis.

Epigenetic therapy is currently approved only for hematological malignancies, and as mentioned earlier its application to solid tumors is actively being investigated [160]. Because epigenetic alterations are induced by infection and the resultant chronic inflammation, it is possible that at least some infection-associated cancers will show a good response to epigenetic therapy. If so, identification of epigenomic signatures in tumors that will respond appears to be a topic worthy of investigation.

Aberrant histone modifications have received relatively limited attention, although they appear to occur more often and much earlier than aberrant DNA methylation in a mouse colitis model [27]. One major reason why only a limited number of studies are available is the technical difficulty of quantifying histone modifications, especially for diagnostic applications. Development of a method for precise measurement of histone modifications would advance the field. From preventative and therapeutic viewpoints, many inhibitors of histone modification enzymes and readers are currently being developed [155], and aberrant histone modification induced by infection may be a promising target.

\section{Abbreviations \\ CIN: Cervical intraepithelial neoplasia; DNMT: DNA methyltransferases; EBV: Epstein-Barr virus; HBV: Hepatitis B virus; HBx: Hepatitis B virus protein X; HCC: Hepatocellular carcinoma; HCV: Hepatitis C virus; HNSCC: Head and neck squamous cell cancers; HPV: Human papillomavirus; hrHPV: High-risk HPV; LMP: Latent membrane protein; NO: Nitric oxide; NPC: Nasopharyngeal cancer; NSAID: Nonsteroidal anti-inflammatory drug; ROS: Reactive oxygen species}

\section{Competing interests}

The authors declare that they have no competing interests.

\section{Authors' contributions}

All authors read and approved the final manuscript.

\section{Acknowledgements}

This work was supported by a fund (15ck0106023h0002 to TU) for the Practical Research for Innovative Cancer Control from Japan Agency for Medical Research and Development, AMED; and Grant-in-Aid for Young Scientists (B) (15 K18420 to $\mathrm{NH}$ ).

Published online: 28 January 2016

\section{References}

1. Moore PS, Chang Y. Why do viruses cause cancer? Highlights of the first century of human tumour virology. Nat Rev Cancer. 2010;10:878-89.

2. de Martel C, Ferlay J, Franceschi S, Vignat J, Bray F, Forman D, et al. Global burden of cancers attributable to infections in 2008: a review and synthetic analysis. Lancet Oncol. 2012;13:607-15.

3. Feitelson MA, Lee J. Hepatitis B virus integration, fragile sites, and hepatocarcinogenesis. Cancer Lett. 2007;252:157-70.

4. Kremsdorf D, Soussan P, Paterlini-Brechot $P$, Brechot $C$. Hepatitis B virus-related hepatocellular carcinoma: paradigms for viral-related human carcinogenesis. Oncogene. 2006;25:3823-33.

5. Levrero M. Viral hepatitis and liver cancer: the case of hepatitis $C$ Oncogene. 2006;25:3834-47.

6. Saha A, Robertson ES. Epstein-Barr virus-associated B-cell lymphomas: pathogenesis and clinical outcomes. Clin Cancer Res. 2011;17:3056-63.

7. Young LS, Rickinson AB. Epstein-Barr virus: 40 years on. Nat Rev Cancer. 2004:4:757-68.

8. Whiteside MA, Siegel EM, Unger ER. Human papillomavirus and molecular considerations for cancer risk. Cancer. 2008;113(10 Suppl):2981-94.

9. Martin D, Gutkind JS. Human tumor-associated viruses and new insights into the molecular mechanisms of cancer. Oncogene. 2008;27 Suppl 2:S31-42.

10. Arora R, Chang Y, Moore PS. MCV and Merkel cell carcinoma: a molecular success story. Curr Opin Virol. 2012:2:489-98.

11. Feng $H$, Shuda M, Chang Y, Moore PS. Clonal integration of a polyomavirus in human Merkel cell carcinoma. Science. 2008;319:1096-100.

12. Uemura N, Okamoto S, Yamamoto S, Matsumura N, Yamaguchi S, Yamakido $M$, et al. Helicobacter pylori infection and the development of gastric cancer. N Engl J Med. 2001;345:784-9.

13. Gunthert U, Schweiger M, Stupp M, Doerfler W. DNA methylation in adenovirus, adenovirus-transformed cells, and host cells. Proc Natl Acad Sci U S A. 1976:73:3923-7.

14. Rubery ED, Newton AA. DNA methylation in normal and tumour virus-transformed cells in tissue culture. I. The level of DNA methylation in BHK21 cells and in BHK21 cells transformed by polyoma virus (PyY cells). Biochim Biophys Acta. 1973;324:24-36.

15. Kang GH, Lee S, Kim WH, Lee HW, Kim JC, Rhyu MG, et al. Epstein-Bar virus-positive gastric carcinoma demonstrates frequent aberrant methylation of multiple genes and constitutes CpG island methylator phenotype-positive gastric carcinoma. Am J Pathol. 2002;160:787-94. 
16. Kang GH, Lee HJ, Hwang KS, Lee S, Kim JH, Kim JS. Aberrant CpG island hypermethylation of chronic gastritis, in relation to aging, gender, intestinal metaplasia, and chronic inflammation. Am J Pathol. 2003;163:1551-6.

17. Maekita T, Nakazawa K, Mihara M, Nakajima T, Yanaoka K, lguchi M, et al. High levels of aberrant DNA methylation in Helicobacter pylori-infected gastric mucosae and its possible association with gastric cancer risk. Clin Cancer Res. 2006;12:989-95.

18. Herceg Z, Paliwal A. Epigenetic mechanisms in hepatocellular carcinoma: how environmental factors influence the epigenome. Mutat Res. 2011;727:55-61.

19. Kaneda A, Matsusaka K, Aburatani H, Fukayama M. Epstein-Barr virus infection as an epigenetic driver of tumorigenesis. Cancer Res. 2012;72:3445-50.

20. Ushijima T, Hattori N. Molecular pathways: involvement of Helicobacter pylori-triggered inflammation in the formation of an epigenetic field defect, and its usefulness as cancer risk and exposure markers. Clin Cancer Res. 2012;18:923-9.

21. Ushijima T. Epigenetic field for cancerization. J Biochem Mol Biol. 2007:40:142-50

22. Asada K, Nakajima T, Shimazu T, Yamamichi N, Maekita T, Yokoi C, et al. Demonstration of the usefulness of epigenetic cancer risk prediction by a multicentre prospective cohort study. Gut. 2015;64:388-96.

23. Birdwell CE, Queen KJ, Kilgore PC, Rollyson P, Trutschl M, Cvek U, et al. Genome-wide DNA methylation as an epigenetic consequence of EpsteinBarr virus infection of immortalized keratinocytes. J Virol. 2014;88:11442-58.

24. Saha A, Jha HC, Upadhyay SK, Robertson ES. Epigenetic silencing of tumor suppressor genes during in vitro Epstein-Barr virus infection. Proc Natl Acad Sci U S A. 2015;112:E5199-207.

25. Niwa T, Tsukamoto T, Toyoda T, Mori A, Tanaka H, Maekita T, et al. Inflammatory processes triggered by Helicobacter pylori infection cause aberrant DNA methylation in gastric epithelial cells. Cancer Res. 2010;70:1430-40.

26. Okamoto Y, Shinjo K, Shimizu Y, Sano T, Yamao K, Gao W, et al. Hepatitis virus infection affects DNA methylation in mice with humanized livers Gastroenterology. 2014;146:562-72.

27. Takeshima H, Ikegami D, Wakabayashi M, Niwa T, Kim YJ, Ushijima T. Induction of aberrant trimethylation of histone $\mathrm{H} 3$ lysine 27 by inflammation in mouse colonic epithelial cells. Carcinogenesis. 2012;33:2384-90

28. Hur K, Niwa T, Toyoda T, Tsukamoto T, Tatematsu M, Yang HK, et al. Insufficient role of cell proliferation in aberrant DNA methylation induction and involvement of specific types of inflammation. Carcinogenesis. 2011;32:35-41.

29. Yoda Y, Takeshima H, Niwa T, Kim JG, Ando T, Kushima R, et al. Integrated analysis of cancer-related pathways affected by genetic and epigenetic alterations in gastric cancer. Gastric Cancer. 2015;18:65-76.

30. Jemal A, Tiwari RC, Murray T, Ghafoor A, Samuels A, Ward E, et al. Cancer statistics, 2004. CA Cancer J Clin. 2004;54:8-29.

31. Wroblewski LE, Peek Jr RM, Wilson KT. Helicobacter pylori and gastric cancer: factors that modulate disease risk. Clin Microbiol Rev. 2010;23:713-39.

32. Forman D, Webb P, Parsonnet J. H pylori and gastric cancer. Lancet. 1994;343:243-4.

33. Ekstrom AM, Held M, Hansson LE, Engstrand L, Nyren O. Helicobacter pylori in gastric cancer established by CagA immunoblot as a marker of past infection. Gastroenterology. 2001;121:784-91.

34. Asaka M, Kato M, Takahashi S, Fukuda Y, Sugiyama T, Ota H, et al. Guidelines for the management of Helicobacter pylori infection in Japan: 2009 revised edition. Helicobacter. 2010;15:1-20.

35. Salama NR, Hartung ML, Muller A. Life in the human stomach: persistence strategies of the bacterial pathogen Helicobacter pylori. Nat Rev Microbiol. 2013;11:385-99.

36. Schreiber S, Bucker R, Groll C, Azevedo-Vethacke M, Garten D, Scheid P, et al. Rapid loss of motility of Helicobacter pylori in the gastric lumen in vivo. Infect Immun. 2005;73:1584-9.

37. Suerbaum S, Michetti P. Helicobacter pylori infection. N Engl J Med 2002;347:1175-86.

38. Charvat H, Sasazuki S, Inoue M, Iwasaki M, Sawada N, Shimazu T, et al. Prediction of the 10-year probability of gastric cancer occurrence in the Japanese population: the JPHC study cohort II. Int J Cancer. 2015. doi: 10.1002/ijc.29705

39. Ushijima T, Sasako M. Focus on gastric cancer. Cancer Cell. 2004;5:121-5.
40. Kim JG, Takeshima H, Niwa T, Rehnberg E, Shigematsu Y, Yoda Y, et al. Comprehensive DNA methylation and extensive mutation analyses reveal an association between the $\mathrm{CpG}$ island methylator phenotype and oncogenic mutations in gastric cancers. Cancer Lett. 2013;330:33-40

41. Wang K, Yuen ST, Xu J, Lee SP, Yan HH, Shi ST, et al. Whole-genome sequencing and comprehensive molecular profiling identify new driver mutations in gastric cancer. Nat Genet. 2014;46:573-82.

42. Cancer Genome Atlas Research Network. Comprehensive molecular characterization of gastric adenocarcinoma. Nature. 2014;513:202-9.

43. Chan AO, Lam SK, Wong BC, Wong WM, Yuen MF, Yeung YH, et al. Promoter methylation of E-cadherin gene in gastric mucosa associated with Helicobacter pylori infection and in gastric cancer. Gut. 2003;52:502-6.

44. Asada K, Ando T, Niwa T, Nanjo S, Watanabe N, Okochi-Takada E, et al. FHL1 on chromosome $\mathrm{X}$ is a single-hit gastrointestinal tumor-suppressor gene and contributes to the formation of an epigenetic field defect. Oncogene. 2013:32:2140-9.

45. Nakajima T, Yamashita S, Maekita T, Niwa T, Nakazawa K, Ushijima T. The presence of a methylation fingerprint of Helicobacter pylori infection in human gastric mucosae. Int J Cancer. 2009;124:905-10.

46. Okochi-Takada E, Hattori N, Tsukamoto T, Miyamoto K, Ando T, Ito S, et al. ANGPTL4 is a secreted tumor suppressor that inhibits angiogenesis. Oncogene. 2013;33:2273-8.

47. Ando T, Yoshida T, Enomoto S, Asada K, Tatematsu M, Ichinose M, et al. DNA methylation of microRNA genes in gastric mucosae of gastric cancer patients: its possible involvement in the formation of epigenetic field defect. Int J Cancer. 2009:124:2367-74.

48. Suzuki H, Yamamoto E, Nojima M, Kai M, Yamano HO, Yoshikawa K, et al. Methylation-associated silencing of microRNA-34b/c in gastric cancer and its involvement in an epigenetic field defect. Carcinogenesis. 2010;31:2066-73.

49. Nakajima T, Maekita T, Oda I, Gotoda T, Yamamoto S, Umemura S, et al. Higher methylation levels in gastric mucosae significantly correlate with higher risk of gastric cancers. Cancer Epidemiol Biomarkers Prev. 2006;15:2317-21.

50. Slaughter DP, Southwick HW, Smejkal W. Field cancerization in oral stratified squamous epithelium; clinical implications of multicentric origin. Cancer. 1953;6:963-8.

51. Machado AM, Figueiredo C, Touati E, Maximo V, Sousa S, Michel V, et al. Helicobacter pylori infection induces genetic instability of nuclear and mitochondrial DNA in gastric cells. Clin Cancer Res. 2009;15:2995-3002.

52. Hatakeyama M. The role of Helicobacter pylori CagA in gastric carcinogenesis. Int J Hematol. 2006;84:301-8.

53. Matsumoto $Y$, Marusawa $H$, Kinoshita K, Endo $Y$, Kou T, Morisawa T, et al. Helicobacter pylori infection triggers aberrant expression of activation-induced cytidine deaminase in gastric epithelium. Nat Med. 2007:13:470-6.

54. Peek Jr RM, Blaser MJ. Helicobacter pylori and gastrointestinal tract adenocarcinomas. Nat Rev Cancer. 2002;2:28-37.

55. Sugiyama A, Maruta F, Ikeno T, Ishida K, Kawasaki S, Katsuyama T, et al. Helicobacter pylori infection enhances N-methyl-N-nitrosourea-induced stomach carcinogenesis in the Mongolian gerbil. Cancer Res. 1998:58:2067-9.

56. Szaleczky E, Pronai L, Molnar B, Berczi L, Feher J, Tulassay Z. Increased cell proliferation in chronic Helicobacter pylori positive gastritis and gastric carcinoma-correlation between immuno-histochemistry and Tv image cytometry. Anal Cell Pathol. 2000;20:131-9.

57. Low HH, Gubellini F, Rivera-Calzada A, Braun N, Connery S, Dujeancourt A, et al. Structure of a type IV secretion system. Nature. 2014;508:550-3.

58. Sasaki M, Joh T, Tada T, Okada N, Yokoyama Y, Itoh M. Altered expression of membrane inhibitors of complement in human gastric epithelium during Helicobacter-associated gastritis. Histopathology. 1998;33:554-60.

59. El-Omar EM, Carrington M, Chow WH, McColl KE, Bream JH, Young HA, et al Interleukin-1 polymorphisms associated with increased risk of gastric cancer. Nature. 2000;404:398-402.

60. Loh M, Koh KX, Yeo BH, Song CM, Chia KS, Zhu F, et al. Meta-analysis of genetic polymorphisms and gastric cancer risk: variability in associations according to race. Eur J Cancer. 2009:45:2562-8.

61. Shigematsu Y, Niwa T, Rehnberg E, Toyoda T, Yoshida S, Mori A, et al. Interleukin-1 beta induced by Helicobacter pylori infection enhances mouse gastric carcinogenesis. Cancer Lett. 2013;340:141-7. 
62. Chan AO, Chu KM, Huang C, Lam KF, Leung SY, Sun YW, et al. Association between Helicobacter pylori infection and interleukin 1 beta polymorphism predispose to CpG island methylation in gastric cancer. Gut. 2007;56:595-7.

63. Qian X, Huang C, Cho CH, Hui WM, Rashid A, Chan AO. E-cadherin promoter hypermethylation induced by interleukin-1beta treatment or H. pylori infection in human gastric cancer cell lines. Cancer Lett. 2008;263:107-13.

64. Tsuji S, Kawano S, Tsujii M, Takei Y, Tanaka M, Sawaoka H, et al. Helicobacter pylori extract stimulates inflammatory nitric oxide production. Cancer Lett. 1996:108:195-200.

65. Hmadcha A, Bedoya FJ, Sobrino F, Pintado E. Methylation-dependent gene silencing induced by interleukin 1 beta via nitric oxide production. J Exp Med. 1999;190:1595-604

66. Nakajima T, Enomoto S, Yamashita S, Ando T, Nakanishi Y, Nakazawa K, et al. Persistence of a component of DNA methylation in gastric mucosae after Helicobacter pylori eradication. J Gastroenterol. 2010;45:37-44.

67. Katsurano M, Niwa T, Yasui Y, Shigematsu Y, Yamashita S, Takeshima H, et al. Early-stage formation of an epigenetic field defect in a mouse colitis model, and non-essential roles of T- and B-cells in DNA methylation induction. Oncogene. 2012;31:342-51.

68. Epstein MA, Achong BG, Barr YM. Virus particles in cultured lymphoblasts from Burkitt's lymphoma. Lancet. 1964;1:702-3.

69. Imai S, Koizumi S, Sugiura M, Tokunaga M, Uemura Y, Yamamoto $N$, et al. Gastric carcinoma: monoclonal epithelial malignant cells expressing EpsteinBarr virus latent infection protein. Proc Natl Acad Sci U S A. 1994;91:9131-5.

70. Fukayama M, Hayashi Y, Iwasaki Y, Chong J, Ooba T, Takizawa T, et al. Epstein-Barr virus-associated gastric carcinoma and Epstein-Barr virus infection of the stomach. Lab Invest. 1994;71:73-81.

71. Uozaki H, Fukayama M. Epstein-Barr virus and gastric carcinoma-viral carcinogenesis through epigenetic mechanisms. Int J Clin Exp Pathol. 2008;1:198-216.

72. Ushiku T, Chong JM, Uozaki H, Hino R, Chang MS, Sudo M, et al. p73 gene promoter methylation in Epstein-Barr virus-associated gastric carcinoma. Int J Cancer. 2007;120:60-6.

73. Ryan JL, Jones RJ, Kenney SC, Rivenbark AG, Tang W, Knight ER, et al. Epstein-Barr virus-specific methylation of human genes in gastric cancer cells. Infect Agent Cancer. 2010;5:27.

74. Matsusaka K, Kaneda A, Nagae G, Ushiku T, Kikuchi Y, Hino R, et al. Classification of Epstein-Barr virus-positive gastric cancers by definition of DNA methylation epigenotypes. Cancer Res. 2011;71:7187-97.

75. Burgos JS. Involvement of the Epstein-Barr virus in the nasopharyngeal carcinoma pathogenesis. Med Oncol. 2005;22:113-21.

76. Gulley ML. Molecular diagnosis of Epstein-Barr virus-related diseases. J Mol Diagn. 2001;3:1-10.

77. Kwong J, Lo KW, To KF, Teo PM, Johnson PJ, Huang DP. Promoter hypermethylation of multiple genes in nasopharyngeal carcinoma. Clin Cancer Res. 2002:8:131-7.

78. Zhou L, Jiang W, Ren C, Yin Z, Feng X, Liu W, et al. Frequent hypermethylation of RASSF1A and TSLC1, and high viral load of Epstein-Barr virus DNA in nasopharyngeal carcinoma and matched tumor-adjacent tissues. Neoplasia. 2005;7:809-15.

79. Seng TJ, Low JS, Li H, Cui Y, Goh HK, Wong ML, et al. The major 8p22 tumor suppressor DLC1 is frequently silenced by methylation in both endemic and sporadic nasopharyngeal, esophageal, and cervical carcinomas, and inhibits tumor cell colony formation. Oncogene. 2007;26:934-44.

80. Brady G, MacArthur GJ, Farrell PJ. Epstein-Barr virus and Burkitt lymphoma. J Clin Pathol. 2007;60:1397-402.

81. Glaser SL, Jarrett RF. The epidemiology of Hodgkin's disease. Baillieres Clin Haematol. 1996;9:401-16.

82. Ok CY, Papathomas TG, Medeiros LJ, Young KH. EBV-positive diffuse large B-cell lymphoma of the elderly. Blood. 2013;122:328-40.

83. Paschos K, Smith P, Anderton E, Middeldorp JM, White RE, Allday MJ. Epstein-Barr virus latency in $B$ cells leads to epigenetic repression and CpG methylation of the tumour suppressor gene Bim. PLoS Pathog. 2009;5:e1000492.

84. Zhang T, Ma J, Nie K, Yan J, Liu Y, Bacchi CE, et al. Hypermethylation of the tumor suppressor gene PRDM1/Blimp-1 supports a pathogenetic role in EBV-positive Burkitt lymphoma. Blood Cancer J. 2014;4:e261.

85. Hansen KD, Sabunciyan S, Langmead B, Nagy N, Curley R, Klein G, et al. Large-scale hypomethylated blocks associated with Epstein-Barr virus-induced B-cell immortalization. Genome Res. 2014;24:177-84.
86. Tsai CN, Tsai CL, Tse KP, Chang HY, Chang YS. The Epstein-Barr virus oncogene product, latent membrane protein 1, induces the downregulation of E-cadherin gene expression via activation of DNA methyltransferases. Proc Natl Acad Sci U S A. 2002;99:10084-9.

87. Tsai CL, Li HP, Lu YJ, Hsueh C, Liang Y, Chen CL, et al. Activation of DNA methyltransferase 1 by EBV LMP1 Involves c-Jun NH-terminal kinase signaling. Cancer Res. 2006;66:11668-76.

88. Hino R, Uozaki H, Murakami N, Ushiku T, Shinozaki A, Ishikawa S, et al. Activation of DNA methyltransferase 1 by EBV latent membrane protein 2A leads to promoter hypermethylation of PTEN gene in gastric carcinoma. Cancer Res. 2009;69:2766-74.

89. Leonard S, Wei W, Anderton J, Vockerodt M, Rowe M, Murray PG, et al. Epigenetic and transcriptional changes which follow Epstein-Barr virus infection of germinal center $B$ cells and their relevance to the pathogenesis of Hodgkin's lymphoma. J Virol. 2011;85:9568-77.

90. Tsai WL, Chung RT. Viral hepatocarcinogenesis. Oncogene. 2010;29:2309-24.

91. Herath $\mathrm{NI}$, Leggett BA, MacDonald GA. Review of genetic and epigenetic alterations in hepatocarcinogenesis. J Gastroenterol Hepatol. 2006;21:15-21.

92. Paterlini-Brechot $P$, Saigo K, Murakami Y, Chami M, Gozuacik D, Mugnier C, et al. Hepatitis $B$ virus-related insertional mutagenesis occurs frequently in human liver cancers and recurrently targets human telomerase gene. Oncogene. 2003;22:3911-6.

93. Fujimoto A, Totoki $Y$, Abe T, Boroevich KA, Hosoda F, Nguyen HH, et al. Whole-genome sequencing of liver cancers identifies etiological influences on mutation patterns and recurrent mutations in chromatin regulators. Nat Genet. 2012;44:760-4.

94. Nakagawa H, Shibata T. Comprehensive genome sequencing of the liver cancer genome. Cancer Lett. 2013;340:234-40.

95. Jeong SW, Jang JY, Chung RT. Hepatitis C virus and hepatocarcinogenesis. Clin Mol Hepatol. 2012;18:347-56.

96. Rosen HR. Emerging concepts in immunity to hepatitis $C$ virus infection. J Clin Invest. 2013:123:4121-30.

97. Kondo Y, Kanai Y, Sakamoto M, Mizokami M, Ueda R, Hirohashi S. Genetic instability and aberrant DNA methylation in chronic hepatitis and cirrhosis-A comprehensive study of loss of heterozygosity and microsatellite instability at 39 loci and DNA hypermethylation on $8 \mathrm{CpG}$ islands in microdissected specimens from patients with hepatocellular carcinoma. Hepatology. 2000:32:970-9.

98. Lambert MP, Paliwal A, Vaissiere T, Chemin I, Zoulim F, Tommasino M, et al. Aberrant DNA methylation distinguishes hepatocellular carcinoma associated with HBV and HCV infection and alcohol intake. J Hepatol. 2011;54:705-15.

99. Gao P, Wong CC, Tung EK, Lee JM, Wong CM, Ng IO. Deregulation of microRNA expression occurs early and accumulates in early stages of HBV-associated multistep hepatocarcinogenesis. J Hepatol. 2011;54:1177-84.

100. Lin CH, Hsieh SY, Sheen IS, Lee WC, Chen TC, Shyu WC, et al. Genome-wide hypomethylation in hepatocellular carcinogenesis. Cancer Res. 2001;61:4238-43.

101. Sakai M, Hibi K, Kanazumi N, Nomoto S, Inoue S, Takeda S, et al. Aberrant methylation of the CHFR gene in advanced hepatocellular carcinoma. Hepatogastroenterology. 2005;52:1854-7.

102. Yuan Y, Wang J, Li J, Wang L, Li M, Yang Z, et al. Frequent epigenetic inactivation of spleen tyrosine kinase gene in human hepatocellular carcinoma. Clin Cancer Res. 2006;12:6687-95.

103. Nishida N, Nagasaka T, Nishimura T, Ikai I, Boland CR, Goel A. Aberrant methylation of multiple tumor suppressor genes in aging liver, chronic hepatitis, and hepatocellular carcinoma. Hepatology. 2008;47:908-18.

104. Hernandez-Vargas H, Lambert MP, Le Calvez-Kelm F, Gouysse G, McKay-Chopin S, Tavtigian SV, et al. Hepatocellular carcinoma displays distinct DNA methylation signatures with potential as clinical predictors. PLOS One. 2010;5, e9749.

105. Hlady RA, Tiedemann RL, Puszyk W, Zendejas I, Roberts LR, Choi JH, et al. Epigenetic signatures of alcohol abuse and hepatitis infection during human hepatocarcinogenesis. Oncotarget. 2014;5:9425-43.

106. Calvisi DF, Ladu S, Gorden A, Farina M, Lee JS, Conner EA, et al. Mechanistic and prognostic significance of aberrant methylation in the molecular pathogenesis of human hepatocellular carcinoma. J Clin Invest. 2007;117:2713-22.

107. Zheng DL, Zhang $L$, Cheng $N$, Xu X, Deng Q, Teng XM, et al. Epigenetic modification induced by hepatitis $B$ virus $X$ protein via interaction with de novo DNA methyltransferase DNMT3A. J Hepatol. 2009;50:377-87. 
108. Galani E, Christodoulou C. Human papilloma viruses and cancer in the post-vaccine era. Clin Microbiol Infect. 2009;15:977-81.

109. Verhoef VM, Bosgraaf RP, van Kemenade FJ, Rozendaal L, Heideman DA, Hesselink AT, et al. Triage by methylation-marker testing versus cytology in women who test HPV-positive on self-collected cervicovaginal specimens (PROHTECT-3): a randomised controlled non-inferiority trial. Lancet Oncol. 2014;15:315-22

110. Chung $\mathrm{CH}$, Gillison ML. Human papillomavirus in head and neck cancer: its role in pathogenesis and clinical implications. Clin Cancer Res. 2009;15:6758-62.

111. Parfenov M, Pedamallu CS, Gehlenborg N, Freeman SS, Danilova L, Bristow CA, et al. Characterization of HPV and host genome interactions in primary head and neck cancers. Proc Natl Acad Sci U S A. 2014;111:15544-9.

112. Munoz N, Bosch FX, de Sanjose S, Herrero R, Castellsague X, Shah KV, et al. Epidemiologic classification of human papillomavirus types associated with cervical cancer. N Engl J Med. 2003;348:518-27.

113. Sanchez-Cespedes M, Esteller M, Wu L, Nawroz-Danish H, Yoo GH, Koch WM, et al. Gene promoter hypermethylation in tumors and serum of head and neck cancer patients. Cancer Res. 2000;60:892-5.

114. Kato K, Hara A, Kuno T, Mori H, Yamashita T, Toida M, et al. Aberrant promoter hypermethylation of p16 and MGMT genes in oral squamous cell carcinomas and the surrounding normal mucosa. J Cancer Res Clin Oncol. 2006;132:735-43

115. Shaw RJ, Liloglou T, Rogers SN, Brown JS, Vaughan ED, Lowe D, et al. Promoter methylation of P16, RARbeta, E-cadherin, cyclin A1 and cytoglobin in oral cancer: quantitative evaluation using pyrosequencing. $\mathrm{Br} J$ Cancer. 2006:94:561-8

116. Colacino JA, Dolinoy DC, Duffy SA, Sartor MA, Chepeha DB, Bradford CR, et al. Comprehensive analysis of DNA methylation in head and neck squamous cell carcinoma indicates differences by survival and clinicopathologic characteristics. PLoS One. 2013;8:e54742.

117. Lechner M, Fenton T, West J, Wilson G, Feber A, Henderson S, et al. Identification and functional validation of HPV-mediated hypermethylation in head and neck squamous cell carcinoma. Genome Med. 2013;5:15.

118. Sartor MA, Dolinoy DC, Jones TR, Colacino JA, Prince ME, Carey TE, et al. Genome-wide methylation and expression differences in $\mathrm{HPV}(+)$ and $\mathrm{HPV}(-)$ squamous cell carcinoma cell lines are consistent with divergent mechanisms of carcinogenesis. Epigenetics. 2011;6:777-87.

119. Richards KL, Zhang B, Baggerly KA, Colella S, Lang JC, Schuller DE, et al. Genome-wide hypomethylation in head and neck cancer is more pronounced in HPV-negative tumors and is associated with genomic instability. PLoS One. 2009;4:e4941.

120. Virmani AK, Muller C, Rathi A, Zoechbauer-Mueller S, Mathis M, Gazdar AF. Aberrant methylation during cervical carcinogenesis. Clin Cancer Res. 2001;7:584-9.

121. Widschwendter A, Gattringer C, Ivarsson L, Fiegl H, Schneitter A, Ramoni A, et al. Analysis of aberrant DNA methylation and human papillomavirus DNA in cervicovaginal specimens to detect invasive cervical cancer and its precursors. Clin Cancer Res. 2004;10:3396-400.

122. Overmeer RM, Henken FE, Bierkens M, Wilting SM, Timmerman I, Meijer CJ et al. Repression of MAL tumour suppressor activity by promoter methylation during cervical carcinogenesis. J Pathol. 2009;219:327-36.

123. Steenbergen RD, Kramer D, Braakhuis BJ, Stern PL, Verheijen RH, Meijer CJ, et al. TSLC1 gene silencing in cervical cancer cell lines and cervical neoplasia. J Natl Cancer Inst. 2004;96:294-305.

124. Overmeer RM, Henken FE, Snijders PJ, Claassen-Kramer D, Berkhof J, Helmerhorst TJ, et al. Association between dense CADM1 promote methylation and reduced protein expression in high-grade CIN and cervical SCC. J Pathol. 2008;215:388-97.

125. Lai HC, Lin YW, Huang RL, Chung MT, Wang HC, Liao YP, et al. Quantitative DNA methylation analysis detects cervical intraepithelial neoplasms type 3 and worse. Cancer. 2010;116:4266-74.

126. Eads CA, Lord RV, Kurumboor SK, Wickramasinghe K, Skinner ML, Long TI, et al. Fields of aberrant CpG island hypermethylation in Barrett's esophagus and associated adenocarcinoma. Cancer Res. 2000;60:5021-6.

127. Yan PS, Venkataramu C, Ibrahim A, Liu JC, Shen RZ, Diaz NM, et al. Mapping geographic zones of cancer risk with epigenetic biomarkers in normal breast tissue. Clin Cancer Res. 2006;12:6626-36.

128. Yang B, Bhusari S, Kueck J, Weeratunga P, Wagner J, Leverson G, et al. Methylation profiling defines an extensive field defect in histologically norma prostate tissues associated with prostate cancer. Neoplasia. 2013;15:399-408.
129. Yamanoi K, Arai E, Tian Y, Takahashi Y, Miyata S, Sasaki H, et al. Epigenetic clustering of gastric carcinomas based on DNA methylation profiles at the precancerous stage: its correlation with tumor aggressiveness and patient outcome. Carcinogenesis. 2015;36:509-20.

130. Nanjo S, Asada K, Yamashita S, Nakajima T, Nakazawa K, Maekita T, et al. Identification of gastric cancer risk markers that are informative in individuals with past H. pylori infection. Gastric Cancer. 2012;15:382-8.

131. Chen KM, Stephen JK, Havard S, Mahan M, Divine G, Worsham MJ. IGSF4 methylation as an independent marker of human papillomavirus-positive oropharyngeal squamous cell carcinoma. JAMA Otolaryngol Head Neck Surg. 2015;141:257-63.

132. Nawaz I, Moumad K, Martorelli D, Ennaji MM, Zhou X, Zhang Z, et al. Detection of nasopharyngeal carcinoma in Morocco (North Africa) using a multiplex methylation-specific PCR biomarker assay. Clin Epigenetics. 2015;7:89.

133. Roh JL, Wang XV, Manola J, Sidransky D, Forastiere AA, Koch WM. Clinical correlates of promoter hypermethylation of four target genes in head and neck cancer: a cooperative group correlative study. Clin Cancer Res. 2013;19:2528-40.

134. Lorincz AT. Cancer diagnostic classifiers based on quantitative DNA methylation. Expert Rev Mol Diagn. 2014;14:293-305.

135. Lin H, Chen TC, Chang TC, Cheng YM, Chen CH, Chu TY, et al. Methylated ZNF582 gene as a marker for triage of women with Pap smear reporting low-grade squamous intraepithelial lesions - a Taiwanese Gynecologic Oncology Group (TGOG) study. Gynecol Oncol. 2014;135:64-8.

136. Louvanto K, Franco EL, Ramanakumar AV, Vasiljevic N, Scibior-Bentkowska D, Koushik A, et al. Methylation of viral and host genes and severity of cervical lesions associated with human papillomavirus type 16. Int J Cancer. 2015;136:E638-45.

137. Luttmer R, De Strooper LM, Berkhof J, Snijders PJ, Dijkstra MG, Uijterwaal $\mathrm{MH}$, et al. Comparing the performance of FAM19A4 methylation analysis, cytology and HPV16/18 genotyping for the detection of cervical (pre)cancer in high-risk HPV-positive women of a gynecologic outpatient population (COMETH study). Int J Cancer. 2015. doi: 10.1002/ijc.29824.

138. Hutajulu SH, Indrasari SR, Indrawati LP, Harijadi A, Duin S, Haryana SM, et al. Epigenetic markers for early detection of nasopharyngeal carcinoma in a high risk population. Mol Cancer. 2011;10:48.

139. Wong TS, Kwong DL, Sham JS, Wei WI, Kwong YL, Yuen AP. Quantitative plasma hypermethylated DNA markers of undifferentiated nasopharyngeal carcinoma. Clin Cancer Res. 2004;10:2401-6.

140. Eads CA, Nickel AE, Laird PW. Complete genetic suppression of polyp formation and reduction of CpG-island hypermethylation in Apc(Min/+) Dnmt1-hypomorphic mice. Cancer Res. 2002;62:1296-9.

141. Hatano Y, Semi K, Hashimoto K, Lee MS, Hirata A, Tomita H, et al. Reducing DNA methylation suppresses colon carcinogenesis by inducing tumor cell differentiation. Carcinogenesis. 2015;36:719-29.

142. Laird PW, Jackson-Grusby L, Fazeli A, Dickinson SL, Jung WE, Li E, et al. Suppression of intestinal neoplasia by DNA hypomethylation. Cell. 1995:81:197-205.

143. Belinsky SA, Klinge DM, Stidley CA, Issa JP, Herman JG, March TH, et al. Inhibition of DNA methylation and histone deacetylation prevents murine lung cancer. Cancer Res. 2003;63:7089-93.

144. Peters SL, Hlady RA, Opavska J, Klinkebiel D, Novakova S, Smith LM, et al. Essential role for Dnmt1 in the prevention and maintenance of MYC-induced T-cell lymphomas. Mol Cell Biol. 2013;33:4321-33.

145. Trowbridge JJ, Sinha AU, Zhu N, Li M, Armstrong SA, Orkin SH. Haploinsufficiency of Dnmt1 impairs leukemia stem cell function through derepression of bivalent chromatin domains. Genes Dev. 2012;26:344-9.

146. Baba S, Yamada Y, Hatano Y, Miyazaki Y, Mori H, Shibata T, et al. Global DNA hypomethylation suppresses squamous carcinogenesis in the tongue and esophagus. Cancer Sci. 2009;100:1186-91.

147. Yoo CB, Chuang JC, Byun HM, Egger G, Yang AS, Dubeau L, et al. Long-term epigenetic therapy with oral zebularine has minimal side effects and prevents intestinal tumors in mice. Cancer Prev Res (Phila). 2008;1:233-40.

148. McCabe MT, Low JA, Daignault S, Imperiale MJ, Wojno KJ, Day ML. Inhibition of DNA methyltransferase activity prevents tumorigenesis in a mouse model of prostate cancer. Cancer Res. 2006;66:385-92.

149. Zorn CS, Wojno KJ, McCabe MT, Kuefer R, Gschwend JE, Day ML. 5-aza-2'deoxycytidine delays androgen-independent disease and improves survival in the transgenic adenocarcinoma of the mouse prostate mouse model of prostate cancer. Clin Cancer Res. 2007;13:2136-43. 
150. Chen M, Shabashvili D, Nawab A, Yang SX, Dyer LM, Brown KD, et al. DNA methyltransferase inhibitor, zebularine, delays tumor growth and induces apoptosis in a genetically engineered mouse model of breast cancer. Mol Cancer Ther. 2012;11:370-82.

151. Niwa T, Toyoda T, Tsukamoto T, Mori A, Tatematsu M, Ushijima T. Prevention of Helicobacter pylori-induced gastric cancers in gerbils by a DNA demethylating agent. Cancer Prev Res (Phila). 2013;6:263-70.

152. Cuzick J, Otto F, Baron JA, Brown PH, Burn J, Greenwald P, et al. Aspirin and non-steroidal anti-inflammatory drugs for cancer prevention: an international consensus statement. Lancet Oncol. 2009;10:501-7.

153. Barnes CJ, Cameron IL, Hardman WE, Lee M. Non-steroidol antiinflammatory drug effect on crypt cell proliferation and apoptosis during initiation of rat colon carcinogenesis. Br J Cancer. 1998;77:573-80.

154. Tseng GY, Lin HJ, Lin HY, Perng CL, Lee FY, Lo WC, et al. Effect of non-steroidal anti-inflammatory drugs on gastric and duodenal prostaglandin concentrations in patients with Helicobacter pylori infection. Hepatogastroenterology. 1999;46:1000-4.

155. Dhanak D, Jackson P. Development and classes of epigenetic drugs for cancer. Biochem Biophys Res Commun. 2014;455:58-69.

156. Hattori N, Ushijima T. Compendium of aberrant DNA methylation and histone modifications in cancer. Biochem Biophys Res Commun. 2014:455:3-9.

157. Cheng AS, Culhane AC, Chan MW, Venkataramu CR, Ehrich M, Nasir A, et al. Epithelial progeny of estrogen-exposed breast progenitor cells display a cancer-like methylome. Cancer Res. 2008;68:1786-96.

158. Smith MT, Guyton KZ, Gibbons CF, Fritz JM, Portier CJ, Rusyn I, et al. Key characteristics of carcinogens as a basis for organizing data on mechanisms of carcinogenesis. Environ Health Perspect. 2015. doi: 10.1289/ehp.1509912.

159. Jackson-Grusby L, Laird PW, Magge SN, Moeller BJ, Jaenisch R. Mutagenicity of 5-aza-2'-deoxycytidine is mediated by the mammalian DNA methyltransferase. Proc Natl Acad Sci U S A. 1997;94:4681-5.

160. Azad N, Zahnow CA, Rudin CM, Baylin SB. The future of epigenetic therapy in solid tumours-lessons from the past. Nat Rev Clin Oncol. 2013;10:256-66.

161. Helmbold P, Lahtz C, Enk A, Herrmann-Trost P, Marsch W, Kutzner H, et al. Frequent occurrence of RASSF1A promoter hypermethylation and Merkel cell polyomavirus in Merkel cell carcinoma. Mol Carcinog. 2009;48:903-9. 